\title{
The Peace-Education Curriculum Desirable for Pre- Primary and Primary Schools in Nigeria: A Religious Perspective
}

\author{
Samuel I. Fabarebo (PhD) \\ Sunday O. Sangotunde (PhD) \\ Gabriel K. Ojetayo (PhD) \\ Department of Religious Studies, \\ Adeyemi College of Education, Ondo State, Nigeria
}

Doi:10.19044/esj.2019.v15n1p214～URL:http://dx.doi.org/10.19044/esj.2019.v15n1p214

\begin{abstract}
This paper focuses on re-appraising the peace-education curriculum already in use in primary schools in Nigeria. It also aims at re-wording the peace education curriculum suitable and relevant for pluralistic religious society and cultural diversity like the Nigerian nation. The research opines that peace-education is the process of acquiring values and knowledge and developing the right attitude, skills, and behaviours to live in harmony with one self, with others, and with the Nigerian multi-ethnicity compositions. The research dwells on the Content Analysis as a methodology for a systematic replicable technique for compressing many words of text into fewer content categories based on explicit rules of coding peace-education techniques desirable for a multi-cultural society like Nigeria. This methodology enables researchers to sift through large volumes of data with relative ease in a systematic fashion. It allows researchers to discover and describe the focus of individuals, groups, government institutions, and agencies or societal involvements in the formulation of peace-education desirable for Pre-primary and Primary education in Nigeria. The researchers also adopted the Critical Discourse Analysis (CDA) that stems from a critical theory of language which sees the use of language as a form of social practice. This will give rise to social practices that are tied to specific societal contexts which are considered as part of the existing social relations that could promote peace in the Nigerian society. The research recommends that right from the pre-primary and primary school levels of education, Nigerian children should be exposed to the spirit of oneness, unity in diversity, and social and religious values that promote peace and harmony. Also, a change of the present curriculum should be effected to reflect a pragmatic peace-education technique that is devoid of religious fanaticism, sectional polarization, cultural distortion, and ethnic
\end{abstract}


parochialism. Its efficiency could only be determined if it is holistic in nature and garnished with sincere religious ingredients.

Keywords: Curriculum, Peace-Education, Religion, Stability

\section{Introduction}

This research acknowledges the numerous United Nations declarations on the importance of peace-education. Ian Harris and John Smyth (2002) have described peace education as a series of teaching encounters that is drawn from people's religion, society, and cultural heritages. This definition infers that peace education is built on people's socio-cultural lives that bear on their desire for peace in our society through proverbial sayings, family life, and cultural endowment that are supposedly imbibed from cradle to grave in the life of a Nigerian child. It also involves the non-violent teachings of all religions in Nigerian multi-religious culture, and religious teaching on the management and maintenance of peace and conflict. This research is aimed at providing the skills for critical analysis of structural arrangements that produce and legitimize injustice and inequality in Nigerian nation. As observed by these researchers, Nigerian nation needs the peace education that will encourage a commitment to peace as a settled disposition. Thus, this would enhance the confidence of the individual as an agent of peace, by informing students and pupils on the consequences of war and social injustice. It would also result to the promotion of the values of peace and just social structures in the country.

This research observed that the theory or philosophy of peace education has been assumed and is not properly articulated by the stakeholders in Nigeria nation. This is why this project aims at encouraging pupils and students to love the world and to imagine a peaceful future, and caring for the pupils and students as an example of how to care for others.

Therefore, this is why this paper particularly focuses on how religiouscultural diversity of the Nigerian nation could be drafted to center on conflict resolution. This is typically focused on the social behavioural systems of conflict and training individuals to resolve interpersonal disputes through religious tolerance and good social and cultural awareness that peace education curriculum advocates for. This research therefore centers on the peace education powered by religious principles and practices outlined in series of teachings and moral instructions associated with conflict and peace. This research postulates that with an increase in religious teachings in all tertiary institutions in Nigeria, there will be the likelihood of decreasing or resolving conflicts, tribal wars, and violence in the country. This is why the researchers have considered the preparation of a curriculum for peace education in Nigeria as a worthwhile academic enterprise at this time of 
national development. The Country has suffered from various forms of devastating situations that have seriously hampered trust, confidence, and peaceful co-existence. The menace of militants from the Niger Delta Region, the ethnic violence and volatility cum herdsmen and farmers rancor from the Benue, and the almost unending Boko Haram defilement of the country's security arrangements of the Nigerian nation are part of the evidences on the table of the researchers for the consideration of a formulation of the curriculum that gives this research more relevance at this time.

\section{Research Methodology}

To achieve the primary aim and the broad objectives of this research, the Content Analysis methodology has been considered fit as a verifiable research tool to unveil the salient meanings of many coded religious and cultural expressions found in the various religious inclinations and multicultural heritages, which Nigerian Children are unavoidably vulnerable to from birth. Since the research basically involves the necessity for the redrawing of a desirable curriculum for teaching and learning of peaceeducation at the pre-primary and primary levels, this methodology provides a more holistic approach in the formulation of the curriculum contents required (Foster, 1996). The method also provides an empirical basis for monitoring techniques as it is the nature of an effective educational curriculum (Stember, 2001).

Also, the Critical Discourse Analysis helps the researchers to consider the implications of people's behavior in the society where these pupils grow up. It assesses the consequences of actions that are considered inimical and jeopardy to the peaceful co-existence of Nigerian people which are wrongly passed on to children of the ages of pre-primary and primary school levels in society and their religious gatherings in the country. As observed by Berelson (1952), Krippendorff (1980) and Weber (1990), the Content Analysis as a methodology is defined as any technique for making inferences by objectively and systematically identifying specified characteristics of messages. It looks at where critical analysis is focused on, how languages are used carelessly, and how wrong doctrines are imbibed by religious leaders. This could be verbal and visual teachings that portray or signal terrorism and religious fanaticism which are inimical to our common existence as a nation. As noted by Janks (1997), Fairelough's approach to CDA is so useful in curriculum studies because it provides multiple points of analytic entries.

Further to all of these research tools is the exegetical method. The word "exegesis" originates from the Greek word exegeisthai, which is a combination of $e x$ - 'out of' and hegeisthai 'to guide, lead'. The core meaning of the term is to guide or lead out of a text its meaning or simply to interpret. Since the research is based on the interpretation of text to unveil the religious 
moral lessons needed to shape the Nigerian children at all levels, the exegetical approach is considered as a verifiable research tool.

This research also adopts historical method as an approach to understand Nigeria's socio-political development, religious clashes, and violence. This helps the researchers to trace the beginning of the noticeable break down of peaceful co-existence in human relationships in Nigerian experience. The paper acknowledges that there were times in Nigeria when religious affiliation was not a criterion for employment, civil service appointments, and for enjoying magnanimity of individuals or for political appointments. The historical method therefore helps to trace and punctuate the point at which relationship and trust broke down or was distorted amongst Nigerians of various backgrounds. Historical method helps to assess where we started, where we are, and how far we have gone in either building peace or distorting peaceful structures in Nigeria.

The research adopts survey and questionnaire method to collect information about population of interest in the process of analyzing figures and percentages. It affords the researchers a predefined series of questions and answers from individuals. This method leads the researchers to sampling technique because not every Nigerian citizen are qualified and accessible to answer the predefined questions. In the sampling technique, subgroup of the population is selected to answer the survey questions. The information collected can be generalized to the entire population of interest based on the relevance of the peace education curriculum needed for Nigerian nation. The respondents are given a list of their answers which led to the provision of scales and frequencies. All these methods are necessary because of the drawing and re-drawing of peace-education curriculum that will be reflective of religious perspective.

\section{The Relevance of Religion to Peace-Education in Nigeria}

Nigeria is more than just a subject of casual intellectual interest. For one thing, Nigeria is of importance to the United States and other global communities. One of the reasons is that it is the ancestral home of many African-Americans, and the U.S market and ethnic and religious diversity are factors threatening the unity of the country since its independence. Nigeria is a country profoundly divided into rival groups based on region, the most basic division being the north versus the south.

Religion is an important factor of concern in all human endeavours, particularly in Nigeria. Roughly half of Nigeria's population is Muslim, with large Christian minority numbering about 40 percent. This research considers all of these lines of fragmentation, ethnicity, region and religion as cross cutting factors that should be considered in drafting a peace education 
curriculum that is powered by religion for peaceful co-existence in a country like this.

The importance of peace education for the sustainability of the Nigerian nation has become germane. A reflection on the current and incessant ethnic clashes in Kaduna South, Niger Delta militant, Boko Haram and Fulani Herdsmen terrorism, and political brutality are indices that this research aims at given considerations. Hooliganism, rapes, and kidnapping have all called for a re-appraisal of the viability of peace-education curriculum and a redrawing or a general over-hauling of the peace-education curriculum for teaching and learning processes in primary, secondary, and tertiary institutions in Nigeria. Although curriculum depends on the perception of the person giving the definition, it must include all the experiences the learners have under the guidance of the school (Oloruntegbe, 2003).

The peace education curriculum which is the task of this research should not be limited to what is obtainable in the classroom environment alone, but should also involve all other activities taking place outside the school environment under the guidance of parents and other members of a particular society. Tyler (1949) observed earlier that curriculum is planned and directed by the school to attain its educational goals. Tyler's (1962) definition gives the four basic elements of curriculum that is considered relevant to this research. The phrase "all of the learning of the students" can be considered to represent both contents and learning experiences that the students are exposed to the school environment. However, Tyler Kerr (1962) opined that these two components of curriculum are obviously means through which students learn. This is why they both see the phrase "planned and directed by the school" as clearly indicating that the elements of learning experiences provided by and implemented in the school are carefully planned and considered germane to successful implementation of the peace education curriculum that this research aims at. This research focuses on such a peace education curriculum that is carefully planned and directed towards the enhancement of peaceful coexistence in a multi-ethnic and religious diversity like Nigeria.

This paper is mindful of the importance of accumulated learning experiences that the individuals are exposed to in Nigeria because of cultural diversity which can heavily influence or determine directly or indirectly the societal peace. Thus, those experiences learnt through the informal education are seen as complementary to those gained from the official curriculum. All these are considered important to the total development of a Nigerian child and the society.

\section{Peace-Education Curriculum for Primary School in Nigeria}

This section carefully examines the peace-education vis-à-vis Religious Studies curricula that are in use in Primary Schools in Ondo State 
as a specimen of the one in use by many states in Nigeria. The researchers observed that the Religious Studies curriculum is well set out as a means of fostering teaching and learning of religious thoughts and instructions. The absence of peace education in the curriculum is glaring and therefore has become the main focus of this research.

This has made a cogent reason for this section to look at the ways of applying the teachings and learning of religious thoughts and instructions to promote the teachings and learning procedures for the enhancement of peaceful co-existence in a multicultural and religious diversity like Nigeria. This section, therefore, considers the step by step setting out of the teaching and learning of the right application of religious thoughts for harmonious living among families, individuals and different components units of Nigerian citizens, as a worthwhile research.

A DRAFT OF THE CURRICULUM: WEEK ONE

\begin{tabular}{|c|c|c|c|c|c|}
\hline \multirow[t]{2}{*}{ Topic } & \multirow{2}{*}{$\begin{array}{l}\text { Performance } \\
\text { Objectives }\end{array}$} & \multicolumn{2}{|l|}{ Activities } & \multirow{2}{*}{$\begin{array}{l}\text { Teaching } \\
\text { and } \\
\text { Learning } \\
\text { Resources }\end{array}$} & \multirow[t]{2}{*}{ Evaluation Guide } \\
\hline & & Teacher & Pupils & & \\
\hline $\begin{array}{l}\text { The meaning } \\
\text { of peace in } \\
\text { Old and New } \\
\text { Testaments. } \\
\text { Note: Shalom } \\
\text { occurs more } \\
\text { than } 250 \\
\text { times in the } \\
\text { Old } \\
\text { Testament } \\
\text { and it appears } \\
\text { in } \\
\text { separate } \\
\text { verses. It is an } \\
\text { important } \\
\text { concept and } \\
\text { word in the } \\
\text { bible. God } \\
\text { purposed all } \\
\text { creatures to } \\
\text { enjoy peace. } \\
\text { Peace is an } \\
\text { essential } \\
\text { characteristics } \\
\text { of God. } \\
\text { Isaiah } 9: 6 \text {, } \\
\text { Isaiah } 53: 5, \\
\text { John } 16: 33 \text {, } \\
\text { I Cor. 14:33. }\end{array}$ & $\begin{array}{l}\text { Pupils should } \\
\text { be able to: } \\
\text { Give a brief } \\
\text { definition of } \\
\text { peace } \\
\text { according to } \\
\text { the bible } \\
\text { concept. } \\
\text { Should know } \\
\text { the origin of } \\
\text { peace. } \\
\text { Should be } \\
\text { able } \\
\text { pronounce } \\
\text { words such as } \\
\text { "shalom" and } \\
\text { "arenei" } \\
\text { which } \\
\text { connote } \\
\text { peace in the } \\
\text { Old and New } \\
\text { Testaments. }\end{array}$ & $\begin{array}{l}\text { Define peace } \\
\text { in biblical } \\
\text { concept to the } \\
\text { pupils. } \\
\text { Trace the } \\
\text { origin of peace } \\
\text { in the bible. } \\
\text { Convey a wide } \\
\text { range of } \\
\text { alternative } \\
\text { words for } \\
\text { peace such as: } \\
\text { soundness, } \\
\text { fulfillment, } \\
\text { completion, } \\
\text { wholeness, } \\
\text { harmony, } \\
\text { tranquility, } \\
\text { security, } \\
\text { wellbeing, } \\
\text { welfare, } \\
\text { friendship, } \\
\text { success and } \\
\text { prosperity. } \\
\text { Guide students } \\
\text { to pronounce } \\
\text { the words and } \\
\text { tell them their } \\
\text { meanings. }\end{array}$ & $\begin{array}{l}\text { Listen to } \\
\text { the } \\
\text { teacher's } \\
\text { explanation } \\
\text { of the } \\
\text { meaning of } \\
\text { peace in } \\
\text { Biblical } \\
\text { concept. } \\
\text { Pronounce } \\
\text { the listed } \\
\text { alternative } \\
\text { words for } \\
\text { peace. }\end{array}$ & $\begin{array}{l}\text { A } \\
\text { cardboard } \\
\text { showing } \\
\text { two } \\
\text { friends } \\
\text { enjoying } \\
\text { peaceful } \\
\text { co- } \\
\text { existence. } \\
\text { A } \\
\text { cardboard } \\
\text { showing } \\
\text { two people } \\
\text { fighting as } \\
\text { the } \\
\text { opposite of } \\
\text { peace. } \\
\text { Flash } \\
\text { cards. }\end{array}$ & $\begin{array}{l}\text { Pupils to: } \\
\text { Pronounce the } \\
\text { alternative words } \\
\text { for peace correctly. } \\
\text { Identify each of the } \\
\text { words and their } \\
\text { meanings } \\
\text { relation to peace } \\
\text { concept. } \\
\text { Pupils should be } \\
\text { able to express } \\
\text { what the bible says } \\
\text { about peace e.g. (a) } \\
\text { something } \\
\text { necessary for } \\
\text { everyone, yet few } \\
\text { get it, (b) as a } \\
\text { desired status in } \\
\text { the world, (c) that } \\
\text { God's intention is } \\
\text { that all should be } \\
\text { agent of peace and } \\
\text { enjoy peace in the } \\
\text { world, (d) peace } \\
\text { has to do with the } \\
\text { actions } \\
\text { attitudes and } \\
\text { individuals. It is a } \\
\text { gift from God to } \\
\text { the world. Isaiah } \\
45: 7 \text {, Lev. 26: } 6 \text {, } \\
\text { John } 14: 27 \text {. }\end{array}$ \\
\hline
\end{tabular}


WEEK TWO

\begin{tabular}{|c|c|c|c|c|c|}
\hline \multirow[t]{2}{*}{ Topic } & \multirow[t]{2}{*}{$\begin{array}{l}\text { Performance } \\
\text { Objectives }\end{array}$} & \multicolumn{2}{|l|}{ Activities } & \multirow{2}{*}{$\begin{array}{l}\text { Teaching } \\
\text { and } \\
\text { Learning } \\
\text { Resources }\end{array}$} & \multirow[t]{2}{*}{$\begin{array}{l}\text { Evaluation } \\
\text { Guide }\end{array}$} \\
\hline & & Teacher & Pupils & & \\
\hline $\begin{array}{l}\text { Peace in } \\
\text { the } \\
\text { family. } \\
\text { Husband } \\
\text { and wife. } \\
\text { Parents } \\
\text { and } \\
\text { children. } \\
\text { Siblings. } \\
\text { In-laws. } \\
\text { Note: } \\
\text { Lk 6:38, } \\
\text { Col. } \\
3: 13, \\
\text { Col. } 3: 8, \\
\text { Prov. } \\
25: 15, \\
\text { Titus } \\
3: 1-2, \\
\text { Phil } \\
2: 3,4\end{array}$ & $\begin{array}{l}\text { Pupils should } \\
\text { be able to: } \\
\text { Define } \\
\text { family. } \\
\text { Identify } \\
\text { members of } \\
\text { the nuclear } \\
\text { and extended } \\
\text { families. } \\
\text { Know who is } \\
\text { a husband } \\
\text { and a wife } \\
\text { according to } \\
\text { Biblical } \\
\text { concept. } \\
\text { Know who } \\
\text { your siblings } \\
\text { are in a } \\
\text { family tree. } \\
\text { Know who } \\
\text { in-laws are in } \\
\text { a family. }\end{array}$ & $\begin{array}{l}\text { For peace to } \\
\text { reign in the } \\
\text { family, the } \\
\text { teacher should } \\
\text { mention these } \\
\text { factors to be } \\
\text { observed by all } \\
\text { family } \\
\text { members. } \\
\text { Family } \\
\text { members must } \\
\text { listen to each- } \\
\text { others } \\
\text { attentively } \\
\text { with an open } \\
\text { mind. } \\
\text { Learn how to } \\
\text { be patient and } \\
\text { mild/humble. } \\
\text { Avoid verbal } \\
\text { or physical } \\
\text { abuse. } \\
\text { Learn how to } \\
\text { forgive and } \\
\text { settle } \\
\text { differences } \\
\text { quickly. } \\
\text { Learn selfless } \\
\text { giving and } \\
\text { sharing. } \\
\text { Learn how to } \\
\text { seek peaceful } \\
\text { living. }\end{array}$ & $\begin{array}{l}\text { Listen to the } \\
\text { teachers' } \\
\text { explanations. } \\
\text { Recite the } \\
\text { teachers' } \\
\text { definition of } \\
\text { family. } \\
\text { Copy brief } \\
\text { notes written } \\
\text { on the } \\
\text { chalkboard. }\end{array}$ & $\begin{array}{l}\text { A copy of } \\
\text { cardboard } \\
\text { showing } \\
\text { the } \\
\text { different } \\
\text { members } \\
\text { of a } \\
\text { family. }\end{array}$ & $\begin{array}{l}\text { Pupils to: } \\
\text { Read the } \\
\text { notes on the } \\
\text { chalkboard. } \\
\text { Attempt the } \\
\text { definition } \\
\text { of family. } \\
\text { Mention the } \\
\text { importance } \\
\text { of family in } \\
\text { a society. } \\
\text { Mention } \\
\text { why peace } \\
\text { is important } \\
\text { in the } \\
\text { family. }\end{array}$ \\
\hline
\end{tabular}


WEEK THREE

\begin{tabular}{|c|c|c|c|c|c|c|}
\hline \multirow[t]{2}{*}{ Topic } & \multirow{2}{*}{$\begin{array}{l}\text { Performance } \\
\text { Objectives }\end{array}$} & \multirow[t]{2}{*}{ Content } & \multicolumn{2}{|l|}{ Activities } & \multirow{2}{*}{$\begin{array}{l}\text { Teaching } \\
\text { and } \\
\text { Learning } \\
\text { Resource } \\
\text { s } \\
\end{array}$} & \multirow{2}{*}{$\begin{array}{l}\text { Evaluation } \\
\text { Guide }\end{array}$} \\
\hline & & & Teacher & Pupils & & \\
\hline $\begin{array}{l}\text { Peace in the } \\
\text { community and } \\
\text { among our } \\
\text { neighbors (Part } \\
\text { I). } \\
\text { (a) The } \\
\text { meaning of } \\
\text { community } \\
\text { and } \\
\text { neighbor. } \\
\text { (b) Why do we } \\
\text { need peace } \\
\text { in our } \\
\text { community? } \\
\text { (c) Why do we } \\
\text { need our } \\
\text { neighbor? } \\
\text { Isaiah } \\
54: 12-13 \text {, } \\
\text { II Sam. } \\
\text { 13:1-22, } \\
\text { Lk. 2:14, } \\
\text { Lev. 19:18 }\end{array}$ & $\begin{array}{l}\text { Explain the } \\
\text { meaning of } \\
\text { a } \\
\text { community } \\
\text { Define with } \\
\text { practical } \\
\text { examples } \\
\text { who our } \\
\text { neighbors } \\
\text { are. } \\
\text { Explain the } \\
\text { importance } \\
\text { of peace in } \\
\text { our } \\
\text { community } \\
\text { The } \\
\text { The } \\
\text { advantages } \\
\text { of having } \\
\text { peace in our } \\
\text { community } \\
\text { - Explain the } \\
\text { reason for } \\
\text { maintaining } \\
\text { peace with } \\
\text { our } \\
\text { nieghbours. } \\
\text { Explain } \\
\text { what we } \\
\text { need to do } \\
\text { to enjoy } \\
\text { peace in our } \\
\text { community } \\
\text { Explain } \\
\text { what } \\
\text { danger we } \\
\text { are exposed } \\
\text { to if there is } \\
\text { no peace in } \\
\text { our } \\
\text { community } \\
\text { and among } \\
\text { our } \\
\text { neighbours. }\end{array}$ & $\begin{array}{l}\text { 1. What is } \\
\text { community? } \\
\text { - a group of } \\
\text { people living } \\
\text { in the same } \\
\text { place or } \\
\text { having a } \\
\text { particular } \\
\text { characteristic } \\
\text { in common. } \\
\text { A people } \\
\text { showing the } \\
\text { same ome } \\
\text { attitudes or } \\
\text { interests in } \\
\text { common. } \\
\text { A people } \\
\text { having the } \\
\text { same norms, } \\
\text { value and } \\
\text { identity in a } \\
\text { given area. } \\
\text { E.g. A } \\
\text { village, ton, } \\
\text { streets or } \\
\text { estate. } \\
\text { Who is my } \\
\text { neighbour? - } \\
\text { a person } \\
\text { living next to } \\
\text { or very near } \\
\text { to you. } \\
\text { Someone } \\
\text { whose house } \\
\text { is situated } \\
\text { next to or } \\
\text { very near } \\
\text { your own. } \\
\text { Someone } \\
\text { whose house } \\
\text { is next door } \\
\text { to yours. } \\
\text { God desire } \\
\text { that all } \\
\text { should } \\
\text { enjoy peace } \\
\text { in the } \\
\text { community. }\end{array}$ & $\begin{array}{l}\text { 1. Explain } \\
\text { to the } \\
\text { pupils that } \\
\text { man must } \\
\text { embrace } \\
\text { the } \\
\text { importanc } \\
\text { e of } \\
\text { communit } \\
\text { y life. } \\
\text { 2. A man } \\
\text { is not an } \\
\text { Island. } \\
\text { 3. It is a } \\
\text { divine } \\
\text { design to } \\
\text { be part of } \\
\text { a } \\
\text { communit } \\
\text { y. } \\
4 . \quad \text { You } \\
\text { need a } \\
\text { neighbor. } \\
5 . \quad \text { You } \\
\text { cannot do } \\
\text { it alone in } \\
\text { life. } \\
6 . \text { There is } \\
\text { a } \\
\text { necessary } \\
\text { link } \\
\text { between } \\
\text { God, } \\
\text { peace and } \\
\text { righteous } \\
\text { ness. } \\
7 . \text { You } \\
\text { cannot } \\
\text { claim to } \\
\text { know God } \\
\text { when you } \\
\text { don't } \\
\text { maintain } \\
\text { peace } \\
\text { among the } \\
\text { communit } \\
\text { y you live. } \\
8 . \quad \text { You } \\
\text { cannot }\end{array}$ & $\begin{array}{l}\text { Should } \\
\text { listen to } \\
\text { the } \\
\text { teachers } \\
\text { explanat } \\
\text { ions. } \\
\text { Should } \\
\text { write } \\
\text { down } \\
\text { some } \\
\text { brief } \\
\text { notes on } \\
\text { the } \\
\text { subject } \\
\text { matter. } \\
\text { Should } \\
\text { sing } \\
\text { some } \\
\text { songs } \\
\text { that best } \\
\text { explain } \\
\text { the } \\
\text { meanin } \\
\text { g of the } \\
\text { importa } \\
\text { nce and } \\
\text { benefits } \\
\text { of } \\
\text { maintai } \\
\text { ning } \\
\text { peace in } \\
\text { our } \\
\text { commu } \\
\text { nity and } \\
\text { with our } \\
\text { neighbo } \\
\text { urs e.g. } \\
\text { Agbajo } \\
\text { wo lafi } \\
\text { soya, } \\
\text { Ajeji } \\
\text { owo kan } \\
\text { ko gbe } \\
\text { eru dori, } \\
\text { etc. }\end{array}$ & 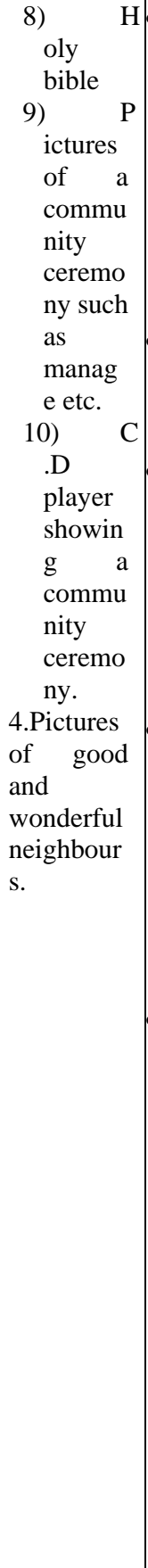 & $\begin{array}{l}\text { Students } \\
\text { should } \\
\text { be able } \\
\text { to } \\
\text { explain } \\
\text { the } \\
\text { meaning } \\
\text { of a } \\
\text { commun } \\
\text { ity. } \\
\text { Define } \\
\text { who a } \\
\text { neighbo } \\
\text { ur is. } \\
\text { Give } \\
\text { reasons } \\
\text { why } \\
\text { peace is } \\
\text { importan } \\
\text { t in our } \\
\text { commun } \\
\text { ity. } \\
\text { Give } \\
\text { reasons } \\
\text { why we } \\
\text { should } \\
\text { maintain } \\
\text { peace } \\
\text { with our } \\
\text { neighbo } \\
\text { urs } \\
\text { Explain } \\
\text { the } \\
\text { dangers } \\
\text { of lack } \\
\text { of peace } \\
\text { in our } \\
\text { commun } \\
\text { ity and } \\
\text { among } \\
\text { our } \\
\text { neighbo } \\
\text { urs. }\end{array}$ \\
\hline
\end{tabular}




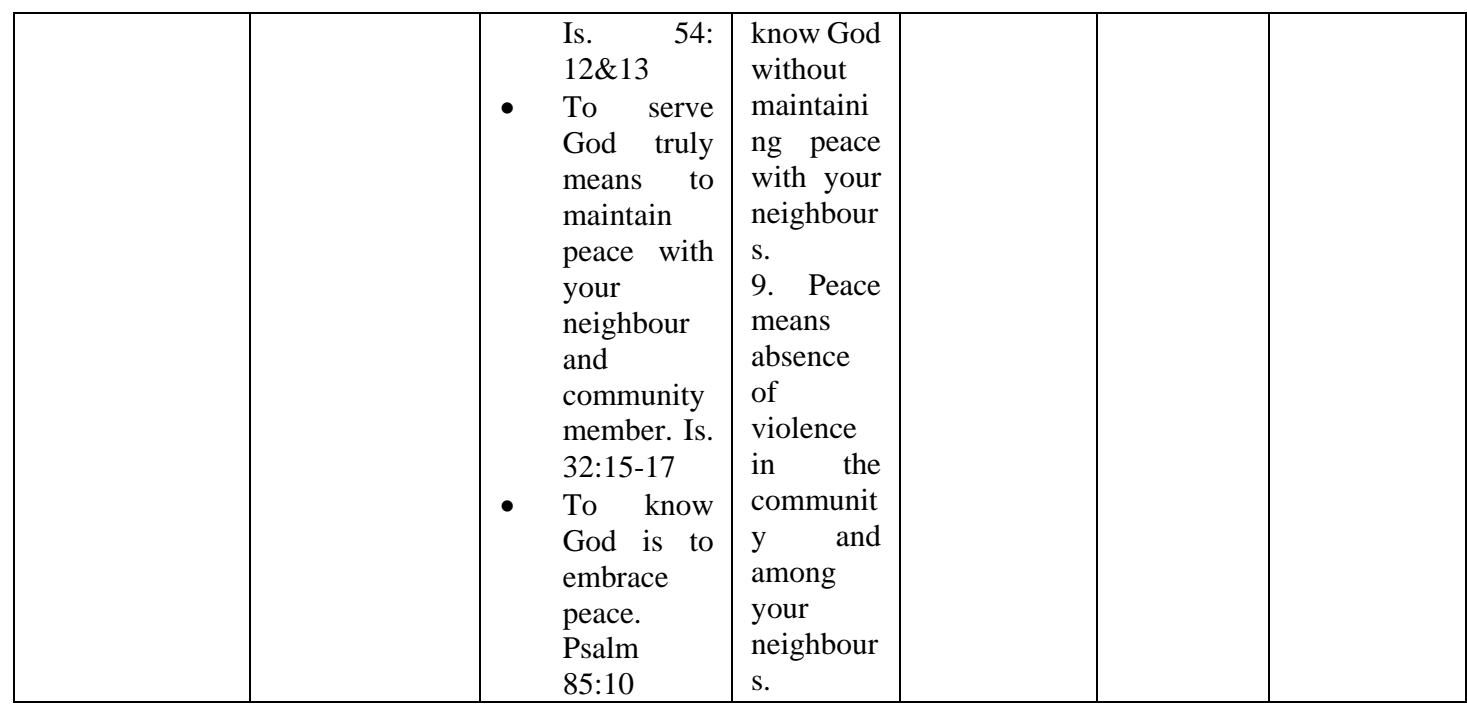

\section{WEEK FOUR}

\begin{tabular}{|c|c|c|c|c|c|}
\hline \multirow[t]{2}{*}{ Topic } & \multirow{2}{*}{$\begin{array}{l}\text { Performance } \\
\text { Objectives }\end{array}$} & \multicolumn{2}{|l|}{ Activities } & \multirow{2}{*}{$\begin{array}{l}\text { Teaching and } \\
\text { Learning } \\
\text { Resources }\end{array}$} & \multirow{2}{*}{$\begin{array}{l}\text { Evaluation } \\
\text { Guide }\end{array}$} \\
\hline & & Teacher & Pupils & & \\
\hline $\begin{array}{l}\text { Peace among } \\
\text { friends and } \\
\text { people of } \\
\text { other } \\
\text { religions. } \\
\text { Religious } \\
\text { Tolerance } \\
\text { Texts: Micah } \\
\text { 4:3-5, Mark } \\
\text { 9:38-40, Lk. } \\
\text { 9:52-56, John } \\
\text { 4:7-27, Acts } \\
\text { 17:10-13 } \\
\text { Acts. 28:30- } \\
31 \text { Romans } \\
\text { 14:1-23 } \\
\text { I Corinth } \\
\text { 10:31\&32 }\end{array}$ & $\begin{array}{l}\text { Pupils should be } \\
\text { able to: } \\
\text { 1. Explain in a } \\
\text { statement who } \\
\text { a friend is } \\
\text { 2. Understand } \\
\text { and mention } \\
\text { the importance } \\
\text { of friendship. } \\
\text { Explain the } \\
\text { meaning of } \\
\text { religious } \\
\text { tolerance. } \\
\text { Discuss why } \\
\text { peace among } \\
\text { people of other } \\
\text { faiths } \\
\text { necessary in } \\
\text { Nigeria. } \\
\text { Explain why } \\
\text { peace is an } \\
\text { essential factor } \\
\text { for unity in } \\
\text { Nigeria. } \\
\text { Consider the } \\
\text { example of } \\
\text { David and } \\
\text { Jonathan. }\end{array}$ & $\begin{array}{l}\text { The teacher } \\
\text { should: } \\
\text { - } \quad \text { Read and } \\
\text { explain the } \\
\text { bible } \\
\text { passage. } \\
\text { Discuss } \\
\text { some good } \\
\text { thing to be } \\
\text { achieved if } \\
\text { there is } \\
\text { peace } \\
\text { among } \\
\text { friends. } \\
\text { Discuss the } \\
\text { reason why } \\
\text { people of } \\
\text { other faiths } \\
\text { should } \\
\text { maintain } \\
\text { peace } \\
\text { among } \\
\text { each other. } \\
\text { Discuss the } \\
\text { danger of } \\
\text { violence } \\
\text { against } \\
\text { people of } \\
\text { other faith } \\
\text { in Nigeria. }\end{array}$ & $\begin{array}{l}\text { Pupils should: } \\
\text { 1. Listen and } \\
\text { ask questions } \\
\text { on the subject } \\
\text { matter. } \\
\text { 2. Write down } \\
\text { notes. } \\
\text { 3. List the } \\
\text { importance of } \\
\text { peace among } \\
\text { friends. } \\
\text { 4. Mention the } \\
\text { advantages of } \\
\text { peace of other } \\
\text { faiths in } \\
\text { Nigeria. }\end{array}$ & $\begin{array}{l}\text { 1. Pictures of } \\
\text { two friends who } \\
\text { enjoy peace in } \\
\text { their } \\
\text { relationship. } \\
2 \text {. Songs of } \\
\text { peace among } \\
\text { friends and } \\
\text { people of } \\
\text { different faith } \\
\text { formations. }\end{array}$ & $\begin{array}{l}\text { Pupils to: } \\
\text { 1. Explain who } \\
\text { a friend is. } \\
\text { 2. Explain the } \\
\text { steps to } \\
\text { maintain peace } \\
\text { among friends. } \\
\text { 3. Explain ways } \\
\text { of maintaining } \\
\text { peace between } \\
\text { Christians and } \\
\text { Muslims. }\end{array}$ \\
\hline
\end{tabular}


WEEK FIVE

\begin{tabular}{|c|c|c|c|c|c|}
\hline \multirow[t]{2}{*}{ Topic } & \multirow[t]{2}{*}{$\begin{array}{l}\text { Performance } \\
\text { Objectives }\end{array}$} & \multicolumn{2}{|l|}{ Activities } & \multirow{2}{*}{$\begin{array}{l}\text { Teaching } \\
\text { and } \\
\text { Learning } \\
\text { Resources }\end{array}$} & \multirow[t]{2}{*}{$\begin{array}{l}\text { Evaluation } \\
\text { Guide }\end{array}$} \\
\hline & & Teacher & upils & & \\
\hline $\begin{array}{l}\text { Peace } \\
\text { among } \\
\text { co- } \\
\text { workers. } \\
\text { Peace in } \\
\text { schools } \\
\text { and } \\
\text { higher } \\
\text { institution } \\
\text { s of } \\
\text { learning. } \\
\text { Reference } \\
\text { s } \\
\text { Dan. 5\&6 } \\
\text { Mark } \\
\text { 12:26-31 } \\
\text { Matt. 7:1- } \\
5 \\
\text { Phil 4:2-3 }\end{array}$ & $\begin{array}{l}\text { 1. Pupils } \\
\text { should } \\
\text { practicalize } \\
\text { peace and } \\
\text { love by } \\
\text { playing } \\
\text { together } \\
\text { irrespective } \\
\text { of the } \\
\text { economic, } \\
\text { religious and } \\
\text { political } \\
\text { status of their } \\
\text { parents. } \\
\text { 2. Pupils } \\
\text { should } \\
\text { share } \\
\text { together. } \\
\text { 3. Work } \\
\text { together } \\
\text { not } \\
\text { minding } \\
\text { their } \\
\text { religious } \\
\text { difference } \\
\text { s. } \\
\text { 4. Identify } \\
\text { the } \\
\text { benefits of } \\
\text { working } \\
\text { together } \\
\text { and } \\
\text { sharing } \\
\text { things } \\
\text { with one } \\
\text { another. }\end{array}$ & $\begin{array}{l}\text { 1. Teacher } \\
\text { should read } \\
\text { and explain } \\
\text { the bible } \\
\text { passages. } \\
\text { 6. Discuss } \\
\text { the } \\
\text { importanc } \\
\text { e of } \\
\text { working } \\
\text { together in } \\
\text { love and } \\
\text { in peace. } \\
\text { 7. Explain } \\
\text { the } \\
\text { advantage } \\
\text { s of } \\
\text { sharing } \\
\text { together in } \\
\text { love and } \\
\text { peace. } \\
\text { 8. Narrate } \\
\text { the stories } \\
\text { of } \\
\text { maintaini } \\
\text { ng peace } \\
\text { at working } \\
\text { places and } \\
\text { showing } \\
\text { together. }\end{array}$ & $\begin{array}{l}\text { 1.Pupils } \\
\text { should } \\
\text { share } \\
\text { things } \\
\text { together } \\
\text { practicall } \\
\text { y. } \\
\text { 2. Carry } \\
\text { out group } \\
\text { work } \\
\text { together } \\
\text { to show a } \\
\text { practical } \\
\text { example } \\
\text { of } \\
\text { working } \\
\text { together } \\
\text { in peace. } \\
\text { 3. Carry } \\
\text { out group } \\
\text { project } \\
\text { together } \\
\text { like } \\
\text { sweeping, } \\
\text { home } \\
\text { economic } \\
\text { s works } \\
\text { and farm } \\
\text { works. }\end{array}$ & $\begin{array}{l}\text { 1. Picture of } \\
\text { working } \\
\text { together } \\
\text { in peace. } \\
\text { 2. Pictures } \\
\text { of people } \\
\text { sharing } \\
\text { together. } \\
\text { 3. Pictures } \\
\text { of a } \\
\text { communit } \\
\text { y work } \\
\text { done in } \\
\text { peace. } \\
\text { 4. Pictures of } \\
\text { students of } \\
\text { different } \\
\text { faith } \\
\text { background } \\
\text { working } \\
\text { together in } \\
\text { the school. }\end{array}$ & $\begin{array}{l}\text { Pupils to: } \\
\text { 5. Ask } \\
\text { questions } \\
\text { from the } \\
\text { teacher } \\
\text { 6. Teacher } \\
\text { asks the } \\
\text { students } \\
\text { questions } \\
\text { to test } \\
\text { how well } \\
\text { they } \\
\text { understoo } \\
\text { d the } \\
\text { subject } \\
\text { matter. } \\
\text { 7lay } \\
\text { games } \\
\text { together } \\
\text { under } \\
\text { teachers' } \\
\text { watch. } \\
\text { Teacher } \\
\text { assesses } \\
\text { the level } \\
\text { of } \\
\text { cooperati } \\
\text { on among } \\
\text { each } \\
\text { other. }\end{array}$ \\
\hline
\end{tabular}


WEEK SIX

\begin{tabular}{|c|c|c|c|c|c|}
\hline \multirow[t]{2}{*}{ Topic } & \multirow{2}{*}{$\begin{array}{l}\text { Performance } \\
\text { Objectives }\end{array}$} & \multicolumn{2}{|l|}{ Activities } & \multirow{2}{*}{$\begin{array}{ll}\text { Teaching and } \\
\text { Learning } \\
\text { Resources }\end{array}$} & \multirow{2}{*}{$\begin{array}{l}\text { Evaluation } \\
\text { Guide }\end{array}$} \\
\hline & & Teacher & Pupils & & \\
\hline $\begin{array}{l}\text { Peace in } \\
\text { schools, } \\
\text { colleges } \\
\text { and } \\
\text { universities. } \\
\text { Important } \\
\text { texts: } \\
\text { Proverbs } \\
\text { 22:6 } \\
\text { Isaiah 41:10 } \\
\text { Psalm 32:8 } \\
\text { Jeremiah } \\
29: 11 \\
\text { Philippians } \\
\text { 4:6-7 } \\
\text { Romans } \\
8: 28 \\
\text { Titus 2:3-5 }\end{array}$ & $\begin{array}{l}\text { The pupils } \\
\text { should be able } \\
\text { to: } \\
\text { 1. Explain the } \\
\text { reason why } \\
\text { peace is } \\
\text { important in } \\
\text { an academic } \\
\text { environment. } \\
\text { 2. Identify } \\
\text { those factors } \\
\text { that could } \\
\text { encourage } \\
\text { peaceful co- } \\
\text { existence in } \\
\text { schools. } \\
\text { 3. Identify } \\
\text { those } \\
\text { activities that } \\
\text { may result } \\
\text { into lack of } \\
\text { peace in } \\
\text { schools. }\end{array}$ & $\begin{array}{l}\text { Teacher should: } \\
\text { 1. Lead the } \\
\text { pupils in } \\
\text { enumerating } \\
\text { those factors } \\
\text { that could } \\
\text { tamper with } \\
\text { peace in } \\
\text { schools and } \\
\text { colleges. } \\
\text { Explain to } \\
\text { the pupils the } \\
\text { importance } \\
\text { of peace to } \\
\text { academic } \\
\text { development } \\
\text { and } \\
\text { fulfillment. } \\
\text { Lead the } \\
\text { students to } \\
\text { examine } \\
\text { those } \\
\text { activities that } \\
\text { could } \\
\text { jeopardize } \\
\text { peace in a } \\
\text { school } \\
\text { environment. } \\
\text { Explain the } \\
\text { implications } \\
\text { of riot, } \\
\text { cultism, and } \\
\text { fighting and } \\
\text { violence to } \\
\text { the } \\
\text { enhancement } \\
\text { of peace in } \\
\text { school environment. }\end{array}$ & $\begin{array}{l}\text { Pupils should: } \\
\text { - Find out the } \\
\text { reason why } \\
\text { involvement } \\
\text { in some } \\
\text { unholy } \\
\text { activities and } \\
\text { behavior } \\
\text { could affect } \\
\text { peace in a } \\
\text { school } \\
\text { environment. } \\
\text { Discover } \\
\text { why they } \\
\text { should seek } \\
\text { peace in a } \\
\text { school } \\
\text { environment. } \\
\text { Listen to the } \\
\text { explanation } \\
\text { of the } \\
\text { teacher. } \\
\text { Live a } \\
\text { peaceful life. } \\
\text { Run away } \\
\text { from anything that } \\
\text { could tamper } \\
\text { with peace in } \\
\text { a school } \\
\text { environment. }\end{array}$ & $\begin{array}{l}\text { - There should } \\
\text { be a display } \\
\text { of a cult } \\
\text { member } \\
\text { arrested by } \\
\text { police. } \\
\text { The picture } \\
\text { of a student } \\
\text { who } \\
\text { embraces } \\
\text { peace in a } \\
\text { school } \\
\text { environment. } \\
\text { Photographs, } \\
\text { cartoons, } \\
\text { video, CDs, } \\
\text { RMS etc. to } \\
\text { show } \\
\text { approved } \\
\text { behavioural } \\
\text { activities and } \\
\text { disapproved } \\
\text { behavioural } \\
\text { activities. } \\
\text { Photos that } \\
\text { show the } \\
\text { danger of } \\
\text { cult and } \\
\text { cultism in a } \\
\text { school } \\
\text { environment. }\end{array}$ & $\begin{array}{l}\text { Pupils to: } \\
\text { 1. Explain the } \\
\text { meaning of } \\
\text { peace in a } \\
\text { school } \\
\text { environment. } \\
\text { 2. Explain why } \\
\text { it is good to } \\
\text { have peace } \\
\text { in a school } \\
\text { environment. } \\
\text { Explain } \\
\text { those factors } \\
\text { that could } \\
\text { affect peace. } \\
\text { Discuss } \\
\text { those things } \\
\text { parents, } \\
\text { teachers, } \\
\text { students, } \\
\text { community, } \\
\text { state and } \\
\text { federal } \\
\text { governments } \\
\text { should do to } \\
\text { enhance } \\
\text { peace in a } \\
\text { school } \\
\text { environment. }\end{array}$ \\
\hline
\end{tabular}


WEEK SEVEN

\begin{tabular}{|c|c|c|c|c|c|}
\hline \multirow[t]{2}{*}{ Topic } & \multirow{2}{*}{$\begin{array}{l}\text { Performance } \\
\text { Objectives }\end{array}$} & \multicolumn{2}{|l|}{ Activities } & \multirow{2}{*}{$\begin{array}{l}\text { Teaching and } \\
\text { Learning } \\
\text { Resources }\end{array}$} & \multirow{2}{*}{$\begin{array}{l}\text { Evaluation } \\
\text { Guide }\end{array}$} \\
\hline & & Teacher & Pupils & & \\
\hline $\begin{array}{l}\text { Peace co- } \\
\text { existence } \\
\text { among } \\
\text { various } \\
\text { cultures } \\
\text { and } \\
\text { Religions } \\
\text { in } \\
\text { Nigeria. } \\
\text { Text: } \\
\text { Quran } \\
4: 1 \\
\text { Quran } \\
49: 13 \\
\text { Quran } \\
42: 13 \\
\text { Quran } \\
2: 136 \\
\text { Quran } \\
5: 82-83 \\
\text { Heb. } \\
9: 28 \\
\text { Rom. } \\
\text { 12:18 } \\
\text { II Tim } \\
4: 1-2 \\
\text { Eph. 4:2 } \\
\text { Rev. } 2: 2\end{array}$ & $\begin{array}{l}\text { Pupils should } \\
\text { be able to: } \\
\text { 1. Explain } \\
\text { the meaning } \\
\text { of cultures. } \\
2 . \quad \text { Identify } \\
\text { some cultures } \\
\text { in Nigeria. } \\
\text { 3.Explain the } \\
\text { importance of } \\
\text { Nigeria } \\
\text { cultural } \\
\text { diversity. } \\
4 . \quad \text { Explain } \\
\text { and identify } \\
\text { different } \\
\text { religious } \\
\text { faiths in } \\
\text { Nigeria. } \\
5 . \quad \text { Explain } \\
\text { Islam as a } \\
\text { religion of } \\
\text { peace. }\end{array}$ & $\begin{array}{l}\text { Teacher } \\
\text { should: } \\
\text { 1. Explain the } \\
\text { meaning of } \\
\text { cultures to } \\
\text { the pupils } \\
\text { with some } \\
\text { familiar } \\
\text { examples. } \\
\text { 2. Discuss } \\
\text { the } \\
\text { importance } \\
\text { of cultures } \\
\text { to Nigerian } \\
\text { unity and } \\
\text { peaceful } \\
\text { co- } \\
\text { existence. } \\
\text { 3. Explain } \\
\text { why all } \\
\text { religion } \\
\text { should } \\
\text { teach peace } \\
\text { and } \\
\text { embrace } \\
\text { peace. } \\
\text { 4. Lead the } \\
\text { pupils to } \\
\text { outline the } \\
\text { importance } \\
\text { of peaceful } \\
\text { co- } \\
\text { existence } \\
\text { among } \\
\text { people of } \\
\text { all } \\
\text { religions in } \\
\text { Nigeria. } \\
\text { 5. Discuss } \\
\text { religious } \\
\text { tolerance in } \\
\text { Nigeria. }\end{array}$ & $\begin{array}{l}\text { Pupils } \\
\text { should: } \\
\text { 1. Listen to } \\
\text { the } \\
\text { teacher. } \\
\text { 2. List the } \\
\text { danger of } \\
\text { lack of } \\
\text { peace } \\
\text { among } \\
\text { people of } \\
\text { different } \\
\text { religion in } \\
\text { Nigeria. } \\
\text { 3.Outline } \\
\text { and write } \\
\text { down the } \\
\text { benefits } \\
\text { and danger } \\
\text { of peace } \\
\text { among } \\
\text { people of } \\
\text { different } \\
\text { faith in } \\
\text { Nigeria. } \\
4 . \text { The } \\
\text { danger of } \\
\text { religious } \\
\text { violence to } \\
\text { Nigerian } \\
\text { youth. }\end{array}$ & 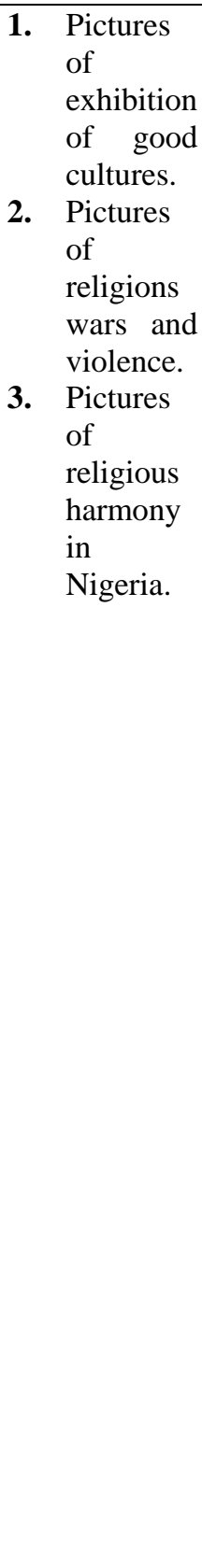 & $\begin{array}{l}\text { Pupils to: } \\
\text { 1. State the } \\
\text { meaning } \\
\text { of } \\
\text { culture. } \\
\text { 2. Explain } \\
\text { types of } \\
\text { culture. } \\
\text { 3. Mention } \\
\text { types of } \\
\text { major } \\
\text { religious } \\
\text { groups in } \\
\text { Nigeria. } \\
\text { Mention } \\
\text { why it is } \\
\text { important } \\
\text { to have } \\
\text { peace } \\
\text { among } \\
\text { religious } \\
\text { group in } \\
\text { Nigeria. } \\
\text { Explain } \\
\text { the } \\
\text { dangers } \\
\text { of not } \\
\text { enjoying } \\
\text { peace } \\
\text { among } \\
\text { groups in } \\
\text { Nigeria. }\end{array}$ \\
\hline
\end{tabular}




\section{Research Outcome/Results}

The study advocates effective teaching and learning of peace education from cradle to grave as a vital ingredient for the development and growth of Nigerian nation.

The researchers also exposed the relevance of religion in the maintenance of peace in Nigeria. The paper shows that religion is a factor for consideration of peace-education, and the moral teachings from the various religious groups should not be underestimated for Nigerian unity. It lays emphasis on the curriculum needed for a heterogeneous society like Nigeria. The research clearly suggests ways to determine the optimal implementation, supervision, and result measurement of the peace-education curriculum at all levels of Nigerian educational structures.

Therefore, the curriculum for peace education, which is major in the contemporary challenges of national integration and national security, is adequately addressed by this research.

The research provides a training manual for the development of societal values and the promotion of good citizenship among Nigerians from primary to university levels and from cradle to grave. The peace-education curriculum which becomes the citizenship education engineered by religion is considered germane to the achievement and the promotion of a better society and God-fearing citizenry that is characterized with good moral standard, love, peace, and harmony. Peace awareness is hereby created and inculcated into every fabric of the country's national life. By this assertion, religion provides answers to all the security, economic, societal, and political challenges that our country is battling with in recent times through the peace education that is powered by religious thoughts.

\section{Conclusion and Recommendations}

The paper makes substantial contributions to the academic and spiritual knowledge of Nigerian culture and religion. It contributes to the relevance of religion and the enhancement of peace and crises resolution and management in Nigeria. This paper exposes not only the academic and spiritual relevance of religion as a viable human agent for peaceful coexistence in Nigeria, but it also exposes the suitability of religious teaching and instructions in the development and restoration of strained relationships among groups, rival communities, and religious fundamentalists during violence and wars. The paper offers some levels of relevance and viability of religious teachings on peace-education in Nigeria to foster growth and development.

Furthermore, this paper focuses on re-drawing or formulating the peace education curriculum suitable for pre-primary, primary, secondary, and tertiary institutions in Nigeria that is powered by religion. It also draws or 
formulates peace education curriculum which enumerates the obligations of all stakeholders involved in the implementation and enhancement of peace agenda in Nigeria.

The curriculum has itemized government's contributions, teachers and pupils/students obligations, and community awareness on the importance of peaceful co-existence for the growth and development of Nigerian nation.

To achieve this, the researchers had collected data from relevant existing books and journals. Also, the researchers had examined the modules used in the three main regions of the country to have a fair understanding of their peace cultures and heritages. During the collection of data for proper analysis, the researchers predefined questions and answers to gather information on the importance of religion to the management of peace in Nigeria. These data collected are critically analyzed through a scientific method found viable for the expressions of facts and figures in scales and frequencies.

Nigerian government and education stakeholders should authorize and assess this curriculum for implementation in all secondary schools in the country. Children should be recoupled and de-oriented from the violent home videos, religious bigotry, and fanaticism by adopting this peace-education curriculum. Many Nigerian youths are vulnerable to a life of violence in recent times because of many violent happenings around them ranging from ethnic violence and brutality, religious terrorism, and home violence. All these are bound to create a wrong perception of what the world actually meant to them. Many see the world as a place for the smartest and a place that is perfused of violence and horrors. This research would put these youth in the right pathway in understanding the reality of what our world is, and also prepare them to take up their fulfilling place in it as agents of peace in their environment and communities.

\section{References:}

1. Berelson, B. (1952). Content Analysis in Communication Research. Glencoe,III: Free Press.

2. Foster, D. (1996). Primary Culprit. New York. Harcourt Brace and World Inc.

3. Harris Ian \& Synott John (2002). Peace Education for a New Century. Social Alternatives, 21(1):3-6.

4. Jank Hilary (1997). Critical Discourse Analysis as a Research Tool. Studies in the Cultural Politics of Education, Vol.18/3.

5. Krippendorff, K. (1980). Content Analysis: An Introduction to Its Methodology. Newbury Park, CA: Sage. 
6. OIoruntegbe, K.O. (2003). Curriculum: Concept, Development, Implementation and Revision Nigeria. Ikare-Akoko: Calvary Ways Publishers.

7. Okebukola, P.O. (2002). Beyond the Stereotype to New Trajectories in Science Teaching. A Publication of the Science Teachers Association of Nigeria. Abuja: Taste and Style Publishing Co.

8. Stemler Steve (2001). Practical Assessment, Research and Evaluation. PARE: Vol.7/17.

9. Tyler, R. K. (1949). Basic Principles of Curriculum and Instruction. USA: University of Chicago Press.

10. Tyler, R.K. (1962). Curriculum Development: Theory and Practice. New York: Harcourt Brace and World Inc.

11. Weber, R.P. (1990). Basic Content Analysis, $2^{\text {nd }}$ ed. Newbury Park, CA. 